\title{
Effect of Different Neem Products on the Mortality and Fitness of Adult Schistocerca gregaria (Forskål)
}

\author{
Z.I.A. Al-Fifi \\ Dept. of Biological Sciences, Faculty of Science, \\ King Abdulaziz University, P. O. Box 80302, \\ Jeddah 21589 Saudi Arabia \\ zalfifi@kau.edu.sa
}

\begin{abstract}
Various neem products were tested against resting and flying Schistocerca gregaria. Two of the products namely neem Azal-F and the unclarified neem oil were obtained from the Company Trifolio, whereas neem oil enriched and pure neem oil, were a gift of Prof. Schmutterer (University of Giessen). The treatment during flight activity caused, for all products applied an increase of the mortality rate, except the neem oil enriched and pure neem oil of Giessen, up to 70 and $90 \%$ respectively. The same products, however, sprayed on resting locusts did not show any remarkable mortality. But this treatment reduced the fitness of the locusts in terms of their flight performance, as well as their adipokinetic potency. In consequence of this, it is to expect that neem treated locusts will not be able to cover long distances. That means the lipid mobilizing system necessary to provide the flight muscles with "fuel" (lipids) is disturbed severely.
\end{abstract}

\section{Introduction}

The desert locust, Schistocerca gregaria (Forskål) (Orthoptera: Acrididae), usually occurs in desert and scrub regions of northern Africa, the Sahel (Burkina Faso, Chad, Mali, Mauritania, and Niger), the Arabian Peninsula (Saudi Arabia, Oman, and Yemen), and southwest Asia (Afghanistan, Iran, India, and Pakistan ${ }^{[1]}$. During the solitary phase, locust populations are low and present no economic threat. After periods of drought, when vegetation flushes occur, in major desert locust breeding areas along the Red Sea coasts, the India/Pakistan border, 
northern Mauritania, and northern Sahel mountain regions, rapid population build-ups, and resultant competition for food occasionally trigger morphological, physiological, and behavioral transformation from solitary to gregarious phases on a regional scale ${ }^{[2-3]}$. Locusts and grasshoppers are major economic pests of crops, and grasslands throughout the world's dry zones. Their attacks attract much public attention; few other pests make headline news, and locusts are the only insect pests mentioned in the Bible and in oral histories of the Sahel ${ }^{[1,4]}$.

The Indian neem tree, Azadirachta indica A. Juss (Meliaceae) is a promising source of botanical insecticides. Due to their relative selectivity, neem products can be recommended for many integrated pest management (IPM) programs ${ }^{[5-10]}$. It is generally believed that the bioactivity of neem is due to the azadirachtin (and other complex limonoids) content ${ }^{[11-12]}$. Azadirachtin is known to have adverse effects on more than 400 insect species ${ }^{[13]}$. Azadirachtin, a limonoid found in the Neem tree, has antifeedant, growth disrupting (also termed moltinhibitory or anti-molting) and lethal effects on a defferent insects species $^{[5,13-18]}$.

Toxicity of neem extracts, such as Azt or different neem preparations, had been reported by many authors against various insect species. El-Sayed ${ }^{[19]}$ observed complete mortality at $0.2-0.5 \%$ of a neem extract in the majority of larval instars of Spodoptera littoralis. Osman ${ }^{[20]}$ observed some different mortalities of Pieris brassicae after treatment of 1-day old 5th instar larvae with 5.0 and 2.5\% Azt On the otherhand, Jagannadh and Nair ${ }^{[21]}$ reported an acute toxic effect of Azt applied against $5^{\text {th }}$ larvae of Spodoptera mauritia. Margosan-O (a neem preparation with $0.3 \%$ Azt content) strongly affected the European corn borer, Ostrinia nubilalis, by feeding larvae on $0.25 \%$ treated corn seedlings ${ }^{[22]}$ and caused mortalities ranging from zero to 70 or $94 \%$ in the spiny boll worm Earias insulana ${ }^{[23]}$. The same neem preparation caused complete larval mortality of the European leaf roller Archips rosanus, within $48 \mathrm{~h}$ of the treatment ${ }^{[24]}$.

Many investigations have been conducted on the antifeedant effects, growth inhibition and abnormal development in various insects caused by neem seed extracts and azadirachtin ${ }^{[25]}$. Neem seed and leaf extracts, as well as, the purified compound azadirachtin, are powerful insect antifeedant and repellents ${ }^{[11-12,26]}$. They may also disrupt growth, inhibit 
moulting $^{[18,27-29]}$ and oogenesis ${ }^{[30-31]}$. All parts of the neem tree, Azadirachta indica, are insecticidal although the seeds possess the largest concentrations of azadirachtin, a steroid-like tetranortriterpenoid. Neem seed extracts have been tested against a large number of insects ${ }^{\text {[24, 32-42]. }}$ However, Schmutterer and Singh ${ }^{[43]}$, as for example, listed 413 insect pest species as sensitive to neem extracts. These extracts have wide ranging biological activities against insects ${ }^{[5,44]}$ including feeding and oviposition deterrence ${ }^{[45]}$, impairing the development ${ }^{[46-47]}$, as well as inhibiting growth, mimicing the juvenile hormone ${ }^{[48]}$. It is noteworthy to mention that, the structural analysis of Azt indicates that it could act as a genotoxic carcinogen ${ }^{[49]}$ and a study of Cohen et al., ${ }^{[50]}$ suggests that the limonoids in the neem extracts could be cytotoxic ${ }^{[51]}$.

\section{Materials and Methods}

Adult locusts S. gregaria were obtained from Ministry of Agriculture, Jeddah branch, Saudi Arabia, and kept in the field cages for about 72 hours prior to beginning the experiments. During the trials, which lasted for 3 months, the days and nights were of equal length (12 hours each), and the daytime and nighttime temperatures were $40^{\circ} \pm 5^{\circ} \mathrm{C}$ and $25^{\circ} \mathrm{C} \pm 5^{\circ} \mathrm{C}$, respectively. The relative humidity was $10-15 \%$ during the daytime, reaching maximum levels of $25-30 \%$ at night. The insects were fed each day with fresh Schouwia thebaica plants.

\section{Products Used and Quantities Applied}

All of the products and control substances were applied using a hand sprayer (Micro Ulva).

\section{Neem Products}

In the studies described here, various neem products from different sources were used in varying concentrations.

a) Enriched neem oil, azadirachtin content: 0,2\% (60 g AZT extract + $439 \mathrm{ml}$ propyl alcohol $+360 \mathrm{ml}$ Span 85 per $3000 \mathrm{ml}$ of neem oil).

b) Pure neem oil, origin of seeds: Republic of India; azadirachtin content: $0.01 \%$. Both of these products were applied at a rate of $10 \mathrm{~L} / \mathrm{ha}$.

c) Azal-F: $80 \%$ filler (blank) $+20 \%$ neem seed extracts; containing 5 $\%$ azadirachtin. 
d) Pure neem oil: $0.04 \%$ azadirachtin and 0.04\% 3-trigloylazadirachtol + approx. $10 \%$ suspended matter.

These products were produced by the Trifolio-M Company (Lahnau, Germany) and applied at rates of 0.5 and $1.0 \mathrm{~L} / \mathrm{ha}$.

\section{Controls}

The following controls were used in all trials:

a) Untreated insects

b) Insects that had been treated with the pure formulation substances and/or additives (vegetable oil, propyl alcohol + Span 85).

\section{Ground Application}

The insects were first immobilized by cooling them to about $4{ }^{\circ} \mathrm{C}$ by keeping them in a refrigerator for 20 minutes, then placed in an arena measuring $16 \mathrm{~m} 2$ in size and fenced by plastic sheet $(1.5 \mathrm{~m} \mathrm{high})$ and sprayed with various products (Micro Ulva, 1 and $10 \mathrm{~L} / \mathrm{ha}$ ).

\section{Flight Application}

Ten insects at a time flying on a flight mill were treated with the indicated substances using ULV techniques. The high of application was $60 \mathrm{~cm}$. The application rates were calculated based on the sprayed volumes per unit of time and the size of the contaminated ground surface (determined by laying out oil-sensitive paper); they were either 2 or 10 $\mathrm{L} / \mathrm{ha}$. Each of the tested populations comprised 20 to 50 individuals, i.e. these applications had to be repeated 2 to 5 times per population. After spraying, the insects flight was continued for another 3 minutes.

\section{Injection and Incubation Trails with Synthetic Adipokinetic Hormone}

These trials were performed using untreated control insects and insects sprayed with various extracts using different methods. Prior to beginning the trials, the individual insects were allowed to rest by themselves for 1.5 to 2 hours. After removing $1 \mu 1$ of hemolymph (from the joint membrane of a hind leg), they were injected with 10 pmol of AKHs dissolved in $10 \mu 1$ of distilled water, using a Hamilton syringe. The injection was performed ventrally through the inter segmental 
membrane between the $1^{\text {st }}$ and $2^{\text {nd }}$ abdominal segments. After an incubation period of 60 minutes, another $1 \mu 1$ of hemolymph was taken. The hemolymph samples were blown into $100 \mu 1$ of concentrated $\mathrm{H}_{2} \mathrm{~S}_{4}$; their lipid content was photometrically determined after hydrolysis using the vanillin reaction ${ }^{[52]}$.

\section{Flight Trials}

An alligator clip that had been filed down to the shape of the pronotum was affixed to the insects, and they were then suspended in the flight mill in such a way that they could deflect out horizontally as a function of their flying speed. This approach permitted testing without causing any injury, so that the same insects could be tested more than once. The total number of rounds flown by 10 insects was captured by a programmable counting device that was operated by an injection coil mounted in the flight mill axis. The outdoor temperatures during all flight trials were between $30^{\circ} \mathrm{C}$ and $34^{\circ} \mathrm{C}$.

\section{Statistical Analysis}

After confirming that the data were normally distributed, statistical significance was tested by Student's t-test. If not mentioned otherwise, significance was calculated on a $95 \%$ level $(\mathrm{P} \leq 0.05)$.

\section{Results and Discussion}

\section{Flight and Ground Application}

The two products made by Trifolio and the enriched oil from India were applied to both resting and flying locusts. The respective mortality rates thus induced are shown in Fig. $1 \& 2$ respectively.

Application of Trifolio neem products to resting insects resulted in $20-25 \%$ mortality, while the enriched neem oil from Giessen only induced slightly higher mortality rates than those exhibited by the untreated controls.

The mortality rates following application of the same products to flying locusts are shown in the Fig. 1. 


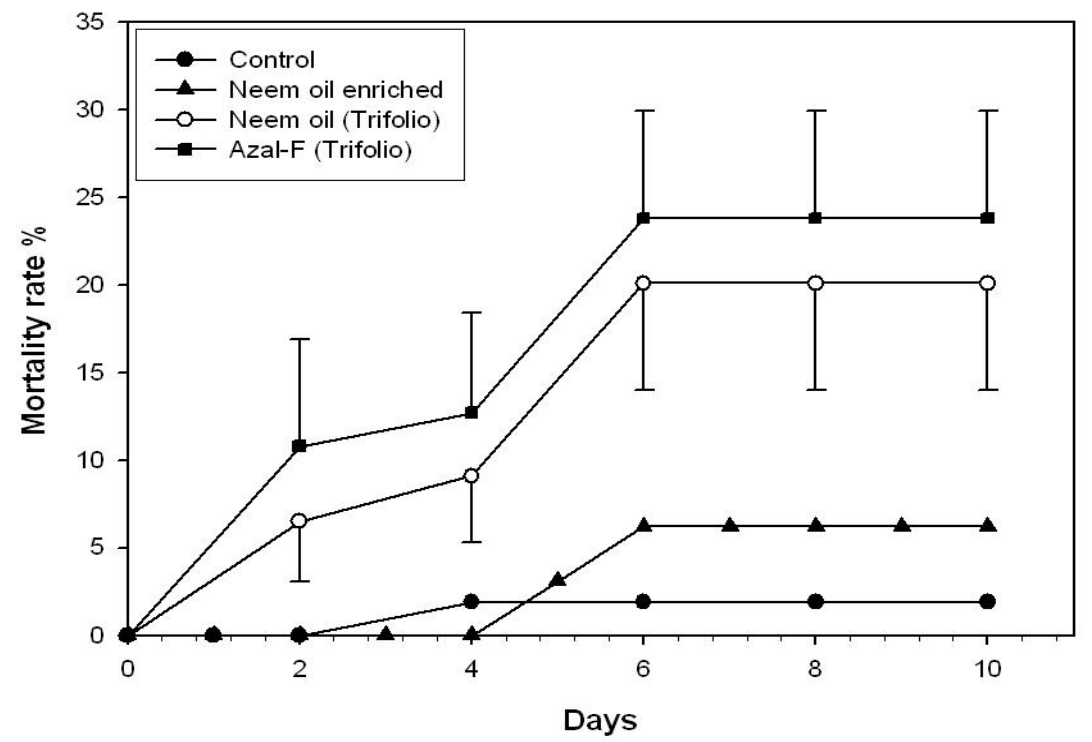

Fig. 1. Mortality rates of $S$. gregaria following application on the ground. The data are the average values \pm SD from 4 trials with 30 insects each. The values without SD were obtained from a trial with 120 insects.

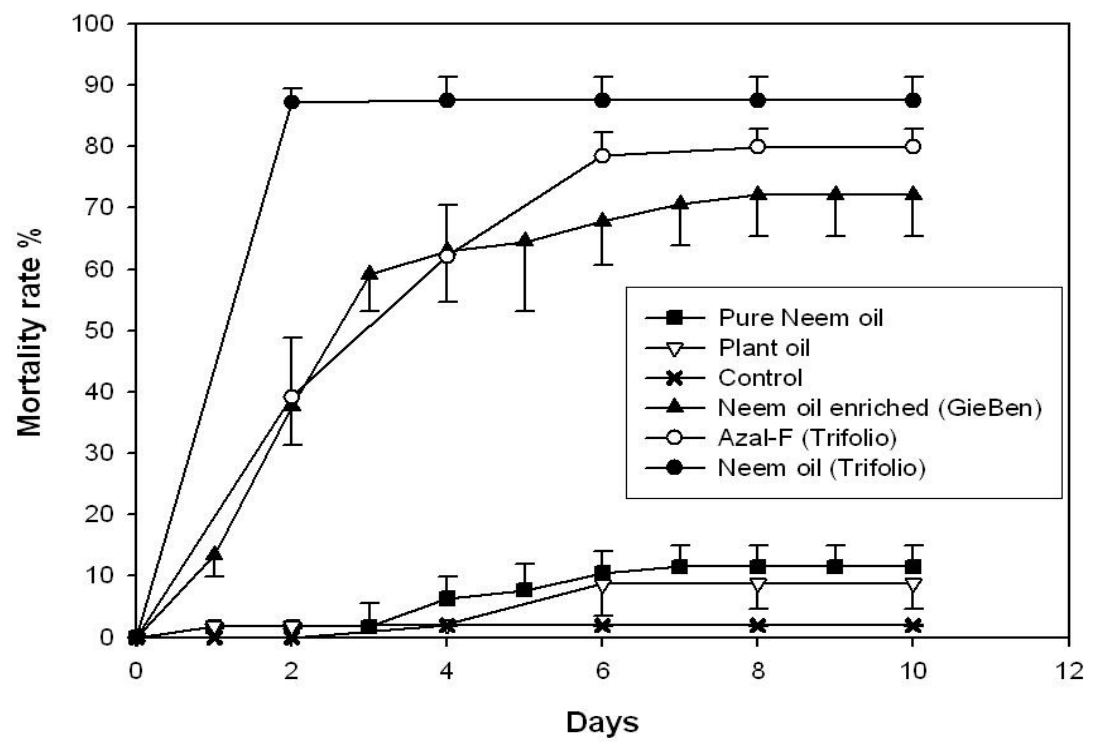

Fig. 2. Mortality rates of $S$. gregaria after flight application. The data represent the average values \pm SD of 3 to 4 trials each with 30 to 48 locusts/trials. Because of the limited capacity of the flight mill, the application process had to be repeated 2 to 7 times for each population. 
The neem oil from the Trifolio Company, which had an azadirachtin content of $0.04 \%$ and an equally high concentration of 3-tigloylazadirachtol, inflicted nearly $90 \%$ mortality within 2 days. The product Azal-F made by the same company and the enriched neem oil from Giessen were somewhat less effective and slower to act. They resulted in mortality rates between $70 \%$ and $80 \%$ over a period of 6 days Fig. 2 .

Compared to the previosly mentioned products, neither the pure neem oil from Giessen (azadirachtin content: 0.007\%) nor the pure vegetable oil applied as a control led to a significant rise in mortality compared to untreated insects.

\section{Studies of Fitness Reduction}

\section{Loss of Flight Ability}

In extended experiments the flight performance of ground and flight treated locusts as well as of untreated and vegetable oil applied locusts was tested Fig. 3 .

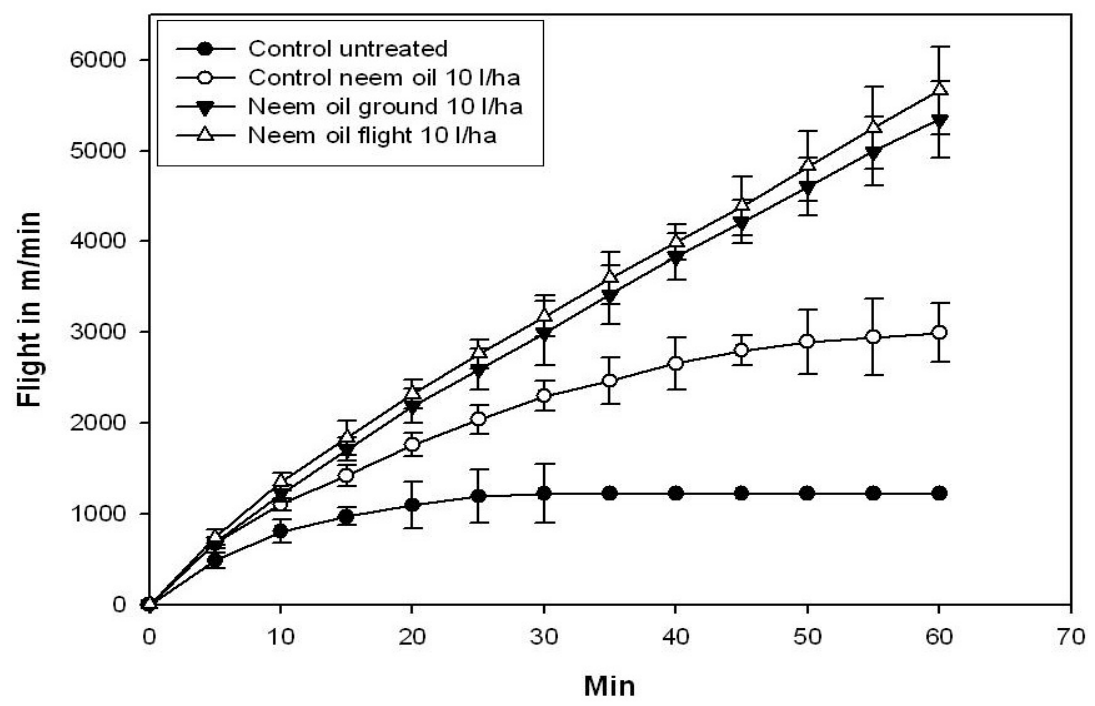

Fig. 3. Flight performance of untreated and palm- and neem oil (ground-flight) treated $S$. gregaria during one hour (c.f. text). The values are the average \pm SD of 3 to 6 experiments for each population.

Untreated and vegetable oil treated $S$. gregaria covered a distance of $5.600 \mathrm{~m} /$ hour nearly. However, the flight performance of the neem treated locusts is reduced drastically. 
Whereas the ground applicated locusts flew nearly the half of that distance covered by the controls, the flight treated $S$. gregaria reached only one third of the controls' achievement. Furtheron, the former were not able for a sustained flight activity taking more than 30 minutes time. After this time it was completely impossible to force the locusts to any further flight activity even by giving intensive mechanical and optical stimuli.

\section{Decrease of Adipokinetic Response}

$S$. gregaria, like nearly all other insects capable of flying long distances, mobilizes lipids stored in the fat body to meet the energy requirements for sustained flight. These lipids are transported in the hemolymph to the flight muscles, where they are completely oxidized to $\mathrm{CO}_{2}$ and $\mathrm{H}_{2} \mathrm{O}$. If it is possible to intervene and reduce this metabolic activity, then this has two consequences for $S$. gregaria. One is that the insect then lacks the fuel it needs for flight activity, and the other is that its water regime is disturbed. In the extremely arid regions inhabited by these insects, the water from oxidation of lipids and other foodstuffs is needed by them to regulate processes at the cellular level.

Lipid release is regulated by adipokinetic hormones (AKHs), which are synthesized by and stored in the corpora cardiaca. At the onset of flight activity, AKHs are released and stimulate the lipase system of the fat body.

In most of the laboratory investigations conducted so far, both extended flight activity and the injection of synthetic adipokinetic hormone have led to increased lipid concentrations in the hemolymph. These concentrations can be utilized as a yardstick for measuring the extent to which diminished flight performance is caused by inhibition or disturbance of the energy-supplying metabolic processes. By injecting synthetic adipokinetic hormone, it is possible to tentatively determine whether reductions in the energy-supplying metabolic processes. By injecting synthetic adipokinetic hormone, it is possible to tentatively determine whether reductions in the energy-supplying metabolism are induced by hormonal disturbances or lowered lipase activity in the fat body. 
Figure 4 shows the changes measured in the lipid content of the hemolymph of untreated control locusts after flight activity and AKHs injection. Injection of AKHs caused an "increase in lipid concentration of nearly $30 \mathrm{mg} / \mathrm{ml}$ in both tested groups. A comparable increase was also exhibited by-the laboratory insects after 60 minutes of flight. The results obtained with field locusts are different; these had a declining lipid concentration after 30 and 60 minutes of flight. In other words, after beginning flight activity the lipids contained in the hemolymph are first used up, and then subsequently supplemented by the reserves in the fat body. As the equally high values after 30 and 60 minutes show, the insects' organisms settle into a floating equilibrium. If the locusts are kept quiet for another 30 minutes and their hemolymph values measured again, it emerges that their lipid content has climbed back to the original resting levels. Since all of the groups responded identically to injection of AKHs, it can be concluded that a hyperlipemic response was present in each of the tested groups. The differences between the laboratory and field locusts after 30 and 60 minutes of flight suggest that the field insects start out by consuming other fuels, e.g. carbohydrates, after beginning flight, a phenomenon that is known from other insects that fly long distances. In this case it may be related to the locusts' phase.

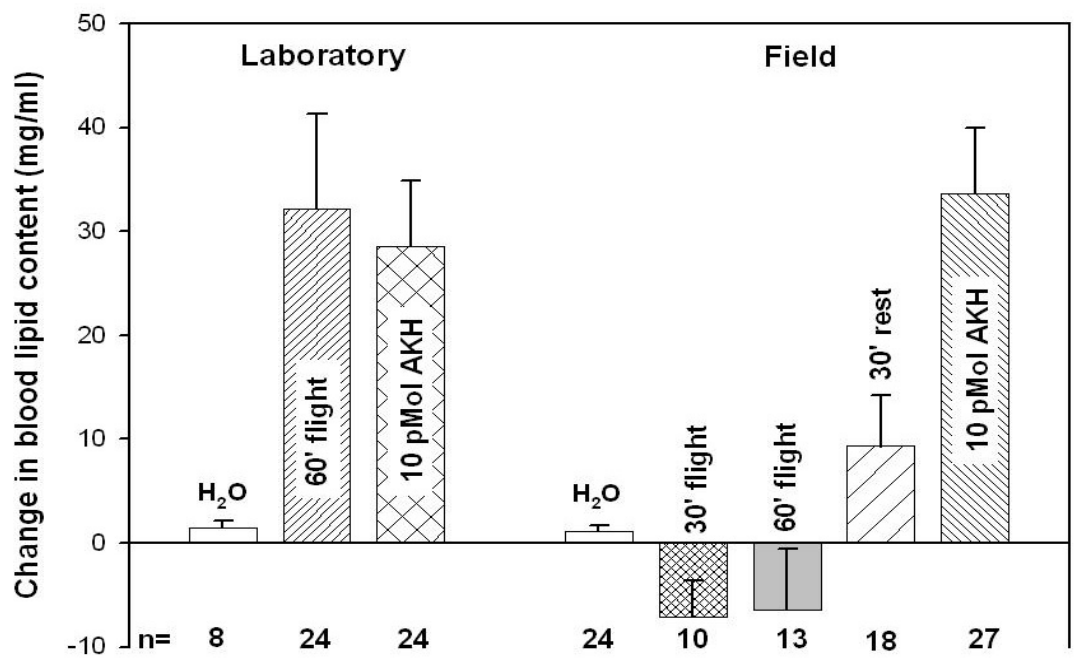

Fig. 4. Changes in hemolymph lipid content after flight activity and a subsequent 30 minute resting period vs injection of $10 \mathrm{p}$ mol AKHs. The data are the average of the injections indicated by $\mathrm{n} \mathrm{H}_{2} \mathrm{O}$ control injections with water to ensure that the injections per se do not induce any changes in the lipid content. 
Since this unexpected finding must first be studied further and verified, it was decided to dispense with altering the lipid content of treated insects by inducing flight. Their adipokinetic responses following injection of AKHs as a function of their prior treatments are shown in Fig. 5.

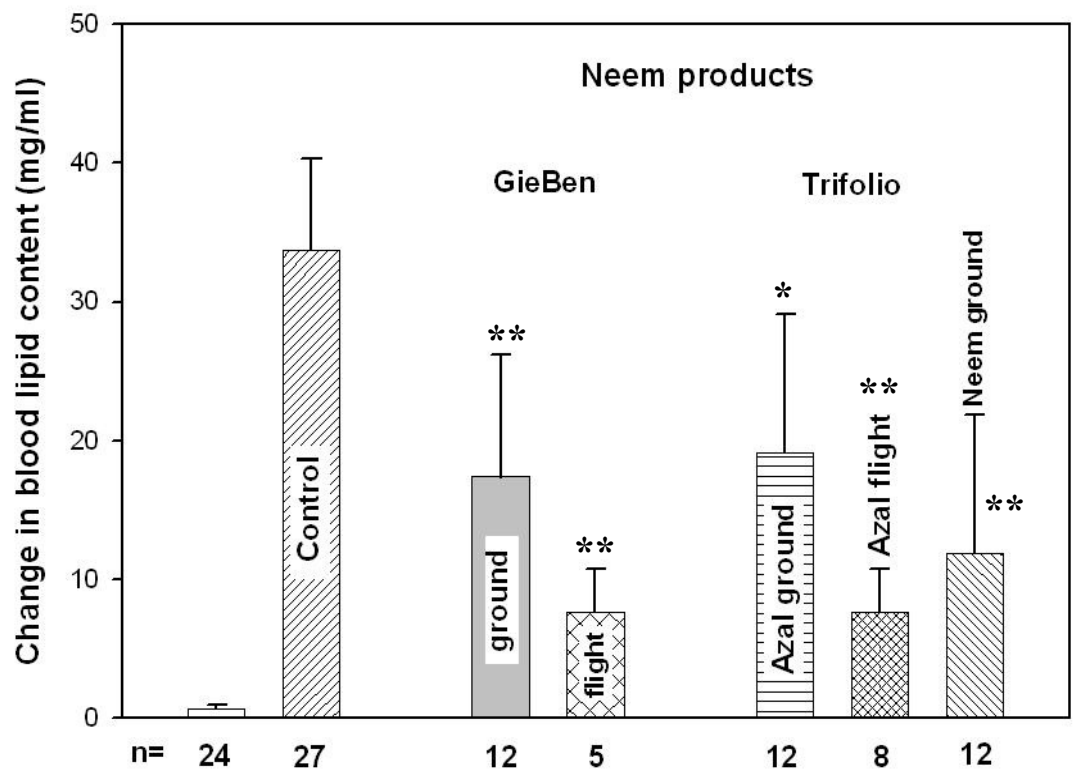

Fig. 5. Changes in lipid content following injection of $S$. gregaria with AKHs 48 hours after treatment with neem products from Giessen or the Trifolio Company. In each case, the data are the average values \pm SD from the number of trials given by $n$.

Ground: application to resting locusts on the ground. Flight: application to flying locusts. Control: untreated field insects. Control lab: untreated laboratory locusts. H20: control injections with water.

Significant differences in comparison the controls are indicated by asterisks. Significance levels: * $\mathbf{p}<0.05 ; * * \mathbf{p}<0.001$.

The two first columns show the changes undergone by the hemolymph lipid concentration of untreated control' insects after injection of $\mathrm{H}_{2} \mathrm{O}$ and AKHs. The application of neem products to resting locusts (ground application) lowers their adipokinetic response by about $50 \%$. Taking account of the standard deviation, it can be assumed that the individuals surviving flight application suffer nearly total loss of their adipokinetic potency. In other words, as potency has already been shown by the flight trials ${ }^{[53-55]}$, these locusts are no longer capable of sustained flight. 
The effects of Azadirachtin on a variety of different insect species have been described, and these effects are due mainly to a disturbance of the hormonal system of the insect by suppression of the concentration of haemolymph ecdysteroids and juvenile hormones ${ }^{[46,56-58]}$. The active ingredient in neem, azadirachtin, interferes with the hormones involved in insect moulting. The result might be delayed moulting, or unsuccessful moulting, The two major hormones involved in insect moulting are ecdysone, which triggers the moult, and juvenile hormone, which determines whether an insect will moult into a juvenile form or not. Azadirachtin also inhibits the transformation of ecdysone to 20hydroxyecdysone. This inhibits chitin synthesis and other reactions necessary for the insect moult.

It is also known that neem products cause antifeedant effects in $S$. gregaria nymphs and adults ${ }^{[18,59-61]}$. The precise mode of action of the active substances contained in neem products - primarily azadirachtin is not known. It has been suggested, however, that azadirachtin directly interacts with the endocrine events responsible for the ecdysteroid and juvenile hormone titres ${ }^{[31,46,61-63]}$. The relation between the respective concentrations of these hormones regulates the growth and development processes which take place during insect metamorphosis.

In various insect species neem products, as well as injected azadirachtin, interfered with the hormonal regulation of flight metabolism and reproduction ${ }^{[56,63-66]}$, and led to reduced or completely inhibited flight ability and fertility ${ }^{[5,67-68]}$.

Neem seed contains $1.5-4.8 \%$ Azadirachtin $^{[69-70]}$, and this is usually extracted by means of organic solvents, the more commonly used ones being acetone, ethanol, methanol and petroleum ether ${ }^{[71-75]}$. The oil is also extracted traditionally by kneading and alternate wetting with hot water until the oil in the dough-like material begins to ooze out ${ }^{76-78]}$.

It seemed that adverse effects of feeding on $S$. gregaria nymphal growth might result from reduced food consumption. This is in agreement with other studies on Locusta migratoria ${ }^{[79-81]}$, which were pointed out that azadirachtin has an inhibitory effect upon gut peristalsis. known effect of azadirachtin, which are predominantly deterrent and growth regulator ${ }^{[13,82-83]}$. Gelbic and Némic ${ }^{[84]}$ wrote that when the nymphs stop feeding, their body weight rapidly declines. Most probably this is due to emptying of the gut and dehydration of tissues prior to next 
stadium. Utilization of food by locust - also by other insects - requires not only that it should be sufficiently palatable to be ingested, but also that the gut should function properly to allow digestion.

The feeding deterrency caused by azadirachtin was manifested by a severely reduced food intake resulting in diminished weight gain compared with controls. This is in general agreement with previous observations $^{[13,85]}$. Trumm and Dorn, ${ }^{[81]}$ reported that the reduction of food intake after the azadirachtin treatment was accompanied and probably caused by a prolonged retention of food in the crop and a strongly retarded passage through the midgut. The effect of azadirachtin on gut physiology have been mostly related to efficiency of diet conversion and inhibition of digestive enzymes ${ }^{[86-87]}$. Timmins and Reynolds, ${ }^{[87]}$ showed that Azadirachtin reduced growth of $M$. sexta larvae due to impaired protein digestion by inhibition of trypsin synthesis and/or secretion by midgut cells. Other hypothesis puts forward to explain this phenomenon: reduction in the haemolymph nutrient content, i.e. proteins, lipids and carbohydrates. The growth rate of insects is generally more closely correlated with nutrient content in the leaves. Also malformation of nymphs are seen and nymphs developed abnormal. Before nymphs moved slowly and had no appetite. Mordue and Blackwell ${ }^{[12]}$ attributed the direct toxicity and rapid mortality to the combined activities of antifeedancy and insect growth regulatory (IGR) effects.

Botanical extract of neem, Azadirachta indica, neem Azal, have been discovered in neem trees. Its active constituent is azadirachtin which concentrated in neem seeds with approximately $40 \%$ oil. Neem Azal F (Trifolio-M GmbH, Germany) is a commercial neem seed extract contains $5 \%$ azadirachtin ${ }^{[44]}$. It has long been knownand widely studied only for phytophagous pest control ${ }^{[88]}$. However no previous investigations were done on its effect on ticks. Therefore, the main target of this study was to evaluate the acaricidal effect of neem Azal F on the egg, immature, and adult stages of $H$. anatolicum excavatum.

\section{Conclusions}

Ground treatment with enriched neem oil did not affect the mortality rate of $S$. gregaria but decreased the flight performance, and influenced the lipid mobilizing system. The same products applied during flight increased the mortality rate up to $70 \%$ and led to a complete inability to 
sustain flight activity, also induced a disruption of the energy mobilizing system. Flight treatment promises a successful strategy for the use of neem products against $S$. gregaria, but further investigations are necessary. The goals of these investigatons must be oriented toward:

1. Varying the formulation to obtain higher concentrations of the effective compounds in neem (to reduce the application volume and to test the feasibility of a ground application).

2. Further dose-response experiments involving various application methods in order to minimize the dosage needed.

3. A better understanding of the mode of action of the neem products. This must include the identification of the most effective compound in the seed kernel extracts.

\section{References}

[1] Steedman, A., (ed.) Locust Handbook, Natural Resources Institute, Chatham, U.K. (1990).

[2] Uvarov, B.P., Bull. Entomol. Res., 12: 135-163 (1921).

[3] Roffey, J. and Popov, G.B., Nature, 219: 446-450 (1968).

[4] Pedgley, D., Desert Locust Forecasting Manual, Vol. 1 and 2, Centre for Overseas Pest Research, London, UK (1981).

[5] Schmutterer, H., Annu. Rev. Entomol., 35: 271 (1990).

[6] Ishida, M., Serit, M., Nakata, K., Juneja, L.R., Kim, M. and Takahashi, S., Biosci. Biotech. Biochem., 56: 1835-1838 (1992).

[7] Koul, O. and Wahab, S., (Eds.), Neem: Today and in the New Millennium, Kluwer Academic Publishers, Netherlands (2004).

[8] Senthil Nathan, S., Chung, P.G. and Murugan, K., Phytoparasitica, 32: 433-443 (2004).

[9] Senthil Nathan, S., Kalaivani, K., Murugan, K. and Chung, P.G., Pesticide Biochem. Physiol., 81: 113-122 (2005a).

[10] Senthil Nathan, S., Kalaivani, K., Murugan, K. and Chung, P.G., Crop Prot., 24: 760763 (2005b).

[11] Butterworth, J.H. and Morgan, E.D., Chem. Commun., 1: 23-24 (1968).

[12] Senthil Nathan, S., Kalaivani, K., Sehoon, K. and Murugan, K., Chemosphere, 62: 1381-1387 (2006).

[13] Mordue (Luntz), A.J. and Blackwell, A., J. Insect Physiol., 39: 903-924 (1993).

[14] Jacobson, M., Focus on Biochemical Pesticides, I, The Neem Tree, CRC Press, Boca Raton, FL. p. (1989).

[15] Arnason, T.J., Philogene, B.J.R., Donskov, N., Hudon, M., Dougal, Mc.C., Foriter, G., Morand, P., Grander, J.D., Lambert, C. and Marris, N.C., Entomol. Exp. Appl., 38: 2934 (1985).

[16] Schmutterer, H., The neem tree Azadirachta indica A. Juss. and other Meliaceous plants: source of unique natural products for integrated pest management, medicine, industry and other purposes, VCH Verlag, Weinheim, Germany. p. 696 (1995).

[17] Ascher, K.R.S., Archs. Insect Biochem. Physiol., 22: 433-449 (1993).

[18] Al-Fifi, Z.I.A., Journal of Entomology, 3: (4) 312-318 (2006).

[19] El-Sayed, E.I., Bull. Ent. Soc. Egypt., 14: 39-47 (1983).

[20] Osman, M.Z., J. Appl. Ent., 115: 254-258 (1993).

[21] Jagannadh, V. and Nair, V., Physiol. Entomol., 17: 56-61 (1992). 
[22] Meisner, J., Ascher, K.R.S. and Aly, R., In H. Schmutterer, K.R.S. Ascher, \& H. Rembold (eds.), Natural pesticides from the neem tree (Azadirachta indica A. Juss.). Proceedings of the First International Neem Conference, Rottach-Egern, GTZ, Eschborn, 297 p. (1981).

[23] Meisner, J. and Nemny, N.E., J. Appl. Entomol., 113: 330-333 (1992).

[24] AliNiazee, M.T., Al Humeyri, A. and Saeed, M., Can. Ent., 129: 27-33 (1997).

[25] Schmutterer, H. and Ascher, K.R.S., (eds.). Proceedings of the Second International Neem Conference, 1983, Rauischholzhausen, GTZ, Eschborn, 587 p. (1984).

[26] Zanno, P.R., Miura, E., Naknishi, K. and Elder, D.L., J. Amer. Chem. Soc., 97: 19751977 (1975).

[27] Koul, O., J. Appl. Entomol., 98: 221-223 (1984).

[28] Garcia, E.D.S. and Rembold, H., J. Insect. Physiol., 30: 939-941 (1984).

[29] Dorn, A., Rademacher, J.M. and Sehn, E., J. Insect. Physiol., 32: 231-238 (1986).

[30] Steets, R., Z. Ang. Ent., 82: 169-176 (1976).

[31] Rembold, H. and Sieber, K.P., Z. Naturf., 36: 466-469 (1981).

[32] Ladd, T.L. Jr., Jacobson, M. and Buriff, C.R., J. Econ. Entomol., 71: 810-813 (1978).

[33] Larew, H.G., Knodel-Montz, J.J., Webb, R.E. and Worthen., J.D. Jr., J. Econ. Entomol., 78: 80-84 (1985).

[34] Saxena, R.C. and Khan, Z.R., J. Econ. Entomol., 79: 39-41 (1985).

[35] Prabhaker, N., Coudriet, D.L., Kishaba, A.N. and Meyerdirk, D.A., Agric. Res. Service, U.S.D. Agric., Riverside, Calif (1986).

[36] Jilani, G., Saxena, R.C. and Rueda, B.P., J. Econ. Entomol., 81: 1226-1230 (1988).

[37] Larew, H.G., J. Econ. Entomol., 81: 593-598 (1988).

[38] Zehnder, G. and Warthen, Jr., J.D., J. Econ. Entomol., 81: 1040-1044 (1988).

[39] Stark, J.D., Vargas, R.I. and Thaiman, R.K., J. Econ. Entomol., 83: 2168-2174 (1990).

[40] Lowery, D.I., Isman, M.B. and Brard, N.L., J. Econ. Entomol., 86: 867-870 (1993).

[41] Naumann, K., Currie, R.W. and Isman, M.B., Evaluation of the repellent effects of a neem insecticide on foraging honey bees and other pollinators, Can. Entomol., 126: $225-$ 230 (1994).

[42] Ghoneim, K.S., Mohamed, H.A. and Bream, A.S., J. Egypt. Ger. Soc. Zool., 33(E): 161179 (2000).

[43] Schmutterer, H. and Singh, R.P., In : "The Neem Tree, Source of Unique Natural Products for Integrated Pest Management, Medicine, Industry and other Purposes", Schmutterer, H., Weinheim (ed.), New York, Basel Cambridge, Tokyo: VCH Publishers (1995).

[44] Isman, M.B., Koul, O., Luczynsk, A. and Keminski, J., J. Argic. Food Chem., 38: 14061411 (1990).

[45] Rice, M.J., Sexton, S. and Esmail, A.M., J. Aust. Ent. Soc., 24: 16 (1985).

[46] Sieber, K.P. and Rembold, H., J. Insect. Physiol., 29: 523-527 (1983).

[47] Barnby, M.A. and Klocke, J.A., J. Insect Physiol., 36(2): 125-131 (1990).

[48] Parakash, A. and Rao, J., Botanical Pesticides in Agriculture, Lewis Publishers (1st ed).) India, 450 p. (1997).

[49] Rozencrantz, H.S. and Klopman, G., Environ. Molec. Mutagenesis, 3: 255-260 (1995).

[50] Cohen, E., Quistad, G.B. and Casida, J.H., Life Sci., 13: 1075-1081 (1996).

[51] Guerrini, V.H., Toowoomba, Queensland, Australia, 4 (3):133-138 (2000).

[52] Zöllner, N. and Kirsch, K., Zeitschrift fur die Gesamte Experimentelle Medizin, 135: 545561 (1962).

[53] Wilps, H., Nasseh, O. and Krall, S., In: Biol. Contr. of Locust and Grasshoppers, pp: $337-$ $346(1991)$.

[54] Wilps, H., Kirkilionis, E. and Muschenich K., Comp. Biochem. Physiol., 102: 67-71 (1992). 
[55] Wilps, H., Nasseh, O., Rembold, H. and Krall, S., Journal of Applied Entomology, 116: 12-19 (1993).

[56] Rembold, H., Muller, T. and Subrahmanyam, B., Z Naturforsch, 43c: 903-907 (1988).

[57] Manal, M.A. and Sehnal, F., Journal of Insect Physiology, 46: 267-274 (2000).

[58] Oberlander, H., Silhacek, D.L. and Porcheron, P., Archives of Insect Biochemistry and Physiology, 28: 209-223 (1995).

[59] Pradhan, S., Jotwani, M.G. and Rai, B.K., Indian Farming, 12: 7-11 (1962).

[60] Nasseh, O., Wilps. H. and Krall, S., In: Kleeberg, H., (ed.) Practice Oriented Results on Use and Production of Neem Ingredients, 79-90 (1992a).

[61] Nasseh, O., Wilps, H. and Krall, S., Pflanzenkrh. Und Pflanzensch., 100: 611-621 (1992b).

[62] Bidmon, H.J., Kauser, G., Mobus, P. and Koolman, J., Proc. 3rd Int. Neem Conf. (Nairobi, 1986), 253, (1987).

[63] Subrahmanyam, B., Muller, T. and Rembold, H., Journal of Insect Physiology, 35: 493500 (1989).

[64] Rembold, H., Uhl, M. and Muller, T., In: Schmutterer, H. and Ascher, K.K.S. (eds), Natural Pesticides from the Neem Tree and other Tropical Plants. GTZ, Eschborn, pp: 289298 (1988).

[65] Rembold, H., Subrahmanyam, B. and Muller, T., Corpus cardiacum-a target for azadirachtin, Experientia, 45: 361-363 (1989).

[66] Dorn. A., Rademacher, J.M. and Sehn, E., In: Schmutterer, H. and Ascher, K.R.S. (eds), Natural Pesticides from the Neem Tree and other Tropical Plants. GTZ, Eschborn, pp: 273288 (1988).

[67] Steffens, R.J. and Schmutterer, H., Zeitschrift fur Angewandte Entomology, 94: 98-103 (1982).

[68] Wilps, H., Zool. Johr. Abt. Fur. Allg. Zool., 93: 271-282 (1989).

[69] Ermel, K., Pahlich, E. and Schmutterer, H., In: Schmutterer, H. and Ascher, K.K.S. (eds), Natural Pesticides from the Neem Tree and other Tropical Plants, Proc. 3rd Int. Neem Conf. (Nairobi, 1986) GTZ Eschborn, Germany. pp: 171-184, (1987).

[70] Ahmed, S. and Grainge, M., International Journal of Development Technology, 3: 123 130 (1985).

[71] Hill, J. and Schoonhoven, A.V., Journal of Economic Entomology, 74: 478-479 (1981).

[72] Sighamony, S., Naidu, M.B. and Osmani, Z., International Pest Control, 25: 120-121 (1983).

[73] Malik, M.M. and Naqvi, S.H.M., Journal of Stored Products Research, 20: 41-44 (1984).

[74] Su, H.C.F., Journal of Economic Entomology, 78: 451-453 (1985).

[75] Lale, N.E.S., Postharvest Biology and Technology, 2: 61-64 (1992).

[76] Grainge, M. and Ahmed, S., Handbook of Plants with Pest Control Properties, Wiley, New York (1988).

[77] Olaifa, J.I. and Adenuga, A.O., Insect Science and its Application, 9: 267-276 (1988).

[78] Stoll, G., Natural Crop Protection Based on Local Farm Resources in the Tropics and Subtropics, third edition. Weikersheim, margraf publishers scientific books, Germany, p. 188 (1988).

[79] Mordue (Luntz), A.J., Cottee, P.K. and Evans, K.A., Physiol. Entomol., 10: 431-437 (1985).

[80] Lomer, C.J., Bateman, R.P., Dent, D., De Groote, H., Douro-Kpindou, O.K., Kooyman, C., Langewald, J., Ouambama, Z., Peveling, R., and Thomas, M., Agricultural and Forest Entomology, 1: 71-88 (1999).

[81] Trumm, P. and Dorn, A., Phytoparasitica, 28(1): 7-26 (2000).

[82] Rahim, M., J. Stored Prod. Res., 34 (2/3): 123-128 (1998).

[83] Govindachari, T.R., Suresh, G., Gopalakrishnan, G. and Wesley, S.D., J. Appl. Ent., 124: 287-291 (2000). 
[84] Gelbic, I. and Némic, V., Acta entmologica bohemoslovaca., 75: 15-24 (1978).

[85] Mordue (Luntz), A.J., Evans, K.A. and Charlet, M., Comparative Biochemistry and Physiology Part C: Comparative Pharmacology and Toxicology, 85: 297-301 (1986).

[86] Koul, O., Shankar, J.S. and Kapil, S., Entamol. Exp. Appl., 79: 43 (1996).

[87] Timmins, W.A. and Reynolds, S.E., Entomologia Exp. Appl., 63: 47-54 (1992).

[88] Dimetry, N.Z. and EI Hawary H.F.M.A., Journal of Applied Entomology, 119 (1): 67-71 (1995). 


\title{
تأثثر منتجات النيم المختلفة على موت ولياقة الأطوار
} البالغة للجر اد الصحر اوي Schistocerca gregaria (Forskål)

\author{
زراق عيسى علي الفيفي \\ قسم علوم الأحياء، كلية العلوم، جامعة الملك عبد العزيز . ص. ب.

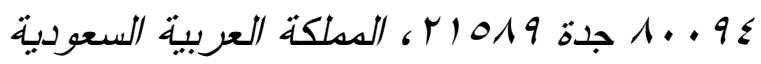

المستخلص. أجريت دراسة تأثثر أنواع مختلفة من منتجات النيم

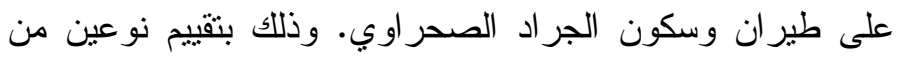

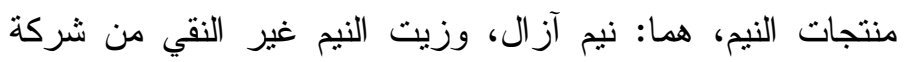
تريفوليو، بينما تم الحصول على زيت نيت النيم المشبع وزيت وزيت النيم النقي كهدية من البروفيسور Schutterer (جامعة جيسين - ألمانيا). أدت معاملة الجر اد بالرش أثناء الطير ان في الحقل بجميع منتجات

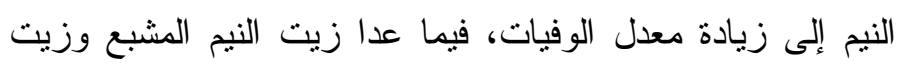

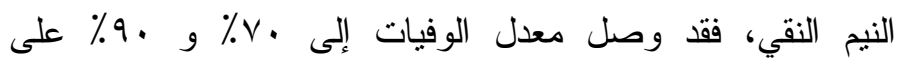

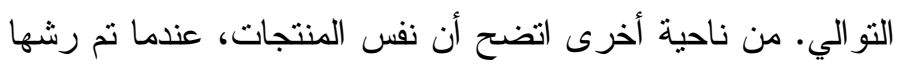

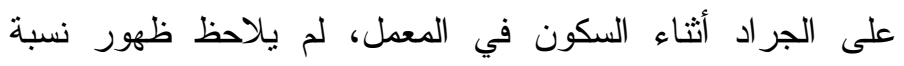

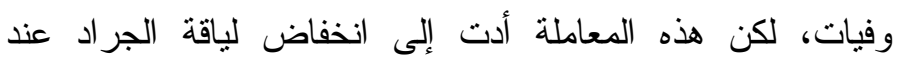

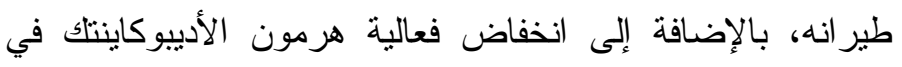

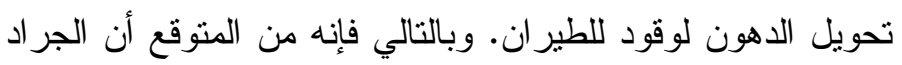

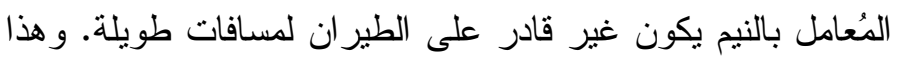

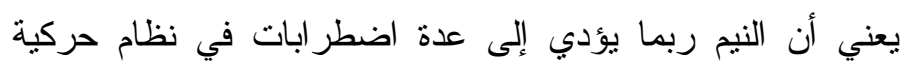
الدهون الضروري لتزويد عضلات الطيران بالوقود (الدهون). 